GENERAL ETHICS

Public health and human values

M Häyry

J Med Ethics 2006;32:519-521. doi: 10.1136/jme.2005.014258

The ends and means of public health activities are suggested to be at odds with the values held by human individuals and communities. Although promoting longer lives in better health for all seems like an endeavour that is obviously acceptable, it can be challenged by equally selfevident appeals to autonomy, happiness, integrity and liberty, among other values. The result is that people's actual concerns are not always adequately dealt with by public health measures and assurances.

Correspondence to:

M Häyry, Centre for Social Ethics and Policy, School of Law, The University of Manchester, Williamson Building, Oxford Road, Manchester M13 9PL, UK; matti.hayry@helsinki.fi

Received6September 2005 In revised form 7 November 2005

Accepted for publication 10 November 2005
O ne way to approach value questions in public health is to identify words that are used, or can be used, in discussions on health promotion. Many people think that some of these words are not mere words, that they have hidden meanings, and that once we have captured those, we have the philosopher's stone to public health. My aim is to show that this is not necessarily true - that the visible and hidden meanings of these words are too diverse to draw simple conclusions.

The paper proceeds in three stages. In the first three sections, I will present the words and sentences that are most often used in describing and justifying public health activities. In the next three sections, I will consider a longer list of words, which may or may not show that there are at least three moral and political approaches to this issue. Finally, I will conclude by asking briefly whether arguments, which are always based on words, can deal with the concerns that people have regarding public health activities.

\section{ENDS AND MEANS}

Public health activities can be described by considering three main questions. What is the aim of these activities? Why is this aim important and good? And by what means do these activities aim to achieve their end?

As to the first question, public health activities seem to aim at longer lives with fewer diseases for everybody. As to the second question, this seems to be an important aim, because, according to public-health-oriented thinking, a longer life with fewer diseases enables people to lead happy, responsible, flourishing lives. And as to the third question, two answers, which are not mutually exclusive, are standardly given. The aim can and should be achieved by studying the conditions of longer lives with fewer diseases, and by implementing policies and measures which can be reasonably expected to promote longer lives with fewer diseases. The first answer refers to the research and the second to the policy aspects.
Note the use of the term "public health activities". This is a reminder that public health can refer to many things, including public health provision, interventions, policy, legislation, research, science, ideology, philosophy and movement. All these usually share the aim, ethos and methods that I have sketched.

\section{MORAL JUSTIFICATION}

Why are public health activities seen as morally justifiable? The main reason is that the three dominant European theories of ethics can easily be bent to support them.

Thinking in terms of consequences (or utility), public health activities can be understood to promote human well-being by scientifically calculated interventions. This is a goal that followers of Jeremy Bentham and John Stuart Mill will find worth aiming at. From the viewpoint of duties and obligations (or the "categorical imperative"), similar activities can be thought to promote people's sense of rational duty towards themselves and others. Champions of Immanuel Kant's moral thinking would find this result satisfying. And when it comes to desirable character traits (or the golden mean in our behaviour), public health promotion can be said to promote good and virtuous lives in a just society. This is something that advocates of Aristotle and aristotelian thinking would like to achieve.

\section{POLITICAL JUSTIFICATION}

Why are public health activities seen as politically justifiable? Perhaps because the main political ideologies of our time can, without much effort, be bent to support them.

Public health activities can be said to promote human freedom from disease and premature death, which is something liberalism requires us to do; to promote equality and equity among people from diverse backgrounds, which are the main items on the egalitarian agenda; to promote solidarity between individuals and nations, which is an important socialist aim; and to promote fellow feeling between members of natural associations, which is something that people with communitarian leanings can endorse.

\section{ALTERNATIVE WORDS}

On the other hand, of course, it may not be like that at all.

Consider, for instance, the following extended lists of words that arguably define three major ethicopolitical approaches to all public activities (table 1).

The lists may be incomplete, and some of the words may be in the wrong places, but the 


\begin{tabular}{|c|c|c|}
\hline $\begin{array}{l}\text { Welfare } \\
\text { liberalism }\end{array}$ & $\begin{array}{l}\text { Traditional } \\
\text { communitarianism }\end{array}$ & $\begin{array}{l}\text { Radical } \\
\text { libertarianism }\end{array}$ \\
\hline $\begin{array}{l}\text { autonomy } \\
\text { non-maleficence } \\
\text { beneficence } \\
\text { justice } \\
\text { efficiency } \\
\text { privacy } \\
\text { consent } \\
\text { confidentiality } \\
\text { safety }\end{array}$ & $\begin{array}{l}\text { integrity } \\
\text { vulnerability } \\
\text { welfare } \\
\text { solidarity } \\
\text { subsidiarity } \\
\text { modesty } \\
\text { legitimacy } \\
\text { data sharing } \\
\text { precaution }\end{array}$ & $\begin{array}{l}\text { liberty } \\
\text { harm avoidance } \\
\text { general happiness } \\
\text { non-violation of rights } \\
\text { non-intervention } \\
\text { individual sphere } \\
\text { voluntariness } \\
\text { control over self } \\
\text { harm prevention or risk } \\
\text { control }\end{array}$ \\
\hline $\begin{array}{l}\text { public interest } \\
\text { transparency } \\
\text { trust } \\
\text { ownership }\end{array}$ & $\begin{array}{l}\text { social democracy } \\
\text { administrative competence } \\
\text { confidence } \\
\text { citizenship }\end{array}$ & $\begin{array}{l}\text { other people's interests } \\
\text { non-interference } \\
\text { scepticism } \\
\text { contract and } \\
\text { compensation }\end{array}$ \\
\hline $\begin{array}{l}\text { openness } \\
\text { equality }\end{array}$ & $\begin{array}{l}\text { honesty } \\
\text { respect }\end{array}$ & $\begin{array}{l}\text { right to ignorance } \\
\text { earned entitlement }\end{array}$ \\
\hline
\end{tabular}

general picture is expected to be accurate, providing the grounds for criticising public health activities from quite a few angles.

\section{CONTESTED ENDS}

How can the ends of public health, as outlined earlier, be criticised? As it happens, easily, and from any of the three angles presented by the lists, if we choose our words conveniently.

The emphasis on longer lives can be counterproductive if the extended length of lives is treated as a goal in itself, as opposed to being a means to happiness, responsibility or flourishing. Longevity is, according to the moral justification of public health activities, a value only in so far as it can be seen to promote a good and worthwhile human existence. This qualification, however, is not always present in practice, and the result is that autonomy, integrity, liberty and welfare are not served. Making lives longer can also be seen as unnatural or against the order of things, if we believe that human life spans have an acceptable, inherent termination point.

The emphasis on "fewer diseases" can have similar effects, as people may value their self-made lifestyle choices more than disease prevention, when these conflict with each other. And it does not matter whether "self-made" is taken to mean what people as individuals prefer, what they see as rational or what is normal in their communities. Public health promotion can, whatever the interpretation, clash with human choices and ways of life.

The egalitarian ideal of health "for everybody", in its turn, can be seen to contradict the requirements of integrity, justice and earned entitlements. Why would we, as a society, be responsible for the lives of people who do not know how to live properly, who do not consider the plight of others in what they do and who claim our resources to cure their selfinflicted ailments? And is it the business of the public health authorities, or the duty of the taxpayers, to promote people's responsibility and flourishing? Can this task not be left to individuals, communities or voluntary associations?

\section{UNSAVOURY MEANS}

How can the means to public health be criticised? In fact, as easily as the ends.

When public health is promoted by studying the conditions of longer and healthier lives, individuals, groups and communities will be placed under a magnifying glass for extended durations. This means constant surveillance, probable intrusions into people's private lives and possible leaks of sensitive information. In addition, experience shows that the topics of study may be selected on moral and political rather than on purely scientific grounds (even assuming that the scientific category exists, which is disputable). The surveillance will, consequently, often be directed to the wrong groups of people to begin with, and the results and applicability of the studies will be questionable.

Furthermore, when public health is promoted by "implementing policies and measures", this is often carried out without consulting the people and communities. The upshot of this is that, at best, benevolent paternalistic control is imposed on people's lives, without their consent or against their will, or that, at worst, detrimental procedures are launched in the name of the common good or public interest.

Also, certain epistemological issues need to be settled. When a public health policy "can be reasonably expected to promote" its aims, whose expectations are we talking about? Whose reasonable judgement are we relying on? Is the knowledge base in question scientific? Or is it perhaps ideological? If it is ideological, what justifies its use? Come to think of it, if it is scientific, what justifies its use?

\section{QUESTIONABLE PREVENTION}

One of the main tenets of public health activities is that prevention should be preferred to cure. Why wait for the onset of ailments when their causes can be eliminated or their effects alleviated more efficiently by prior measures? Amazingly, even this clear and concise insight can be challenged by the ethicopolitical considerations outlined in the lists of words.

Primary prevention implies that people will be targeted before the onset of a condition. Examples of this include immunisations, sex education, seat belt laws and crash helmet regulations. But immunisations entail individual risks, sex education is sometimes seen as indecent, and obligatory seat belts and crash helmets are intrusive. Also, resources allocated to primary prevention are not allocated to emergency services, and this can raise concerns.

Secondary prevention attempts to identify and treat asymptomatic people. Screening for genetic mutations and other indicators falls under this category. But do we want to know about dormant or potential conditions which we may or may not have, and which may or may not affect our health? And should abortions be allowed on the grounds of prenatal tests, when this means that human lives are terminated to halt hereditary diseases?

Tertiary prevention aims at minimising the effects of diseases. It is treatment with an eye on future developments in a person's condition. But what counts as a disease? Do people have a disease if their skin is fair and burns easily in the sun? And what if the condition is self-inflicted and therefore in some sense deserved?

\section{RESIDUAL CONCERNS}

Let us call the objections that can be formulated in terms of moral words "concerns", and let us call the justifications given to public health activities "arguments". The question then is, "Can arguments deal with concerns?"

Three examples will illustrate the difficulties encountered.

Imagine the following exchanges between a concerned citizen and a public health expert:

Doctor, doctor, I'm worried that if my son hears about condoms at school, he will buy some and become engaged in sexual experimentation, which is against his religion. 
But all teenagers will encounter sex at some point, and condoms will safeguard him against most sexually transmittable diseases.

Oh, that's all right, then. Thank you ever so much, doctor.

Doctor, doctor, I have heard that one in a million infants will die if they are vaccinated against polio. What if my child is one of them?

But vaccination programmes are in the public interestalmost every child will be better off, if most of them are immunised.

Oh, thank you, doctor, I am so relieved to hear that.

Doctor, doctor, my sister just killed herself because the screening agency told her that her gene BRCAl was altered, and the newspaper said that she will die of breast cancer.

Actually, the predictive power of BRCAl has been discredited years ago, so your sister had no reason to overreact like that.

Oh, good. Thank you, doctor, I will tell that in the funeral.

If any of the imaginary responses given to the soothing words of the experts sounds less than convincing, it seems that public health arguments do not deal with all the concerns that people have.

A couple of specifics need to be added to this conclusion. One is that people do have other important concerns that are considered by public health activities. People worry about their own well-being, parents are anxious about the health of their children and communities can be mindful of the costs of popular lifestyle choices. Public health measures in many cases provide good responses to these concerns.

The good and useful aspects of some public health activities do not, however, provide a blanket justification for all of them. This is because population-level measures usually have many kinds of consequences besides the originally intended beneficial effect. Consider the third case illustrated above, on breast cancer testing. Public health authorities can argue that the damage done is caused by the misrepresentation of the predictive powers of BRCAl in the mass media. Although this is partly true, the accusation misses an important point. The media representation is influential only in an environment of "breast cancer awareness", which has been created by the authorities themselves. As they want to claim the glory of reduced cancer rates, they should also accept the responsibility for the anxieties and over-reactions that are bound to occur in a less than perfect world inhabited by less than fully rational people who do not always think and act in ways the public authorities would like them to do.

\section{ACKNOWLEDGEMENTS}

This article was produced as a part of the projects "Public Policies, Law and Bioethics: A Framework for Producing Public Health Policy Across the European Union by Examining Concepts of European and Universal Ethical Standards (EuroPHEN)", financed between 2003 and 2006 by the European Community (QLRT-2001-02320), and Ethical and Social Aspects of Bioinformatics (ESABI), financed between 2004 and 2007 by the Academy of Finland (SA 105139).

Competing interests: None. 